\title{
PERFIS BAUXÍTICOS EM CONCEIÇÃO DO MUQUI (ES): PRIMEIROS RESULTADOS
}

\author{
J.B.Sigolo \\ I.S.Silva ${ }^{2}$ \\ M.C.Toledo-Groke ${ }^{1}$ \\ N.Angeli ${ }^{3}$
}

O estado do Espírito Santo apresenta várias ocorrências bauxfticas, derivadas da laterização das rochas de composição granítica que dominam seu território. Neste trabalho, foi estudada uma ocorrência no sul do estado, a cerca de $3,5 \mathrm{~km}$ a NE da sede do município de Conceição do Muqui.

O perfil observado tem cerca de doze metros de altura e expõe três níveis diferenciados sobre a rocha sã, da base para o topo, na seguinte ordem:

- rocha sã: ortognaisse com textura média a grosseira, com quartzo, feldspato alcalino (ortoclásio e microclínio), plagioclásio e biotita. Como acessórios, aparecem anfibólios. piroxênios, muscovita, opacos (magnetita), zircão e granada.

- isalterita porosa: $3 \mathrm{~m}$ de espessura média, com transição gradual para a rocha sã. Apresenta degradação parcial dos minerais primários para caulinita, gibbsita e goethita. Já neste nivel basal ocorrem feições iluviais e volumes irregulares e disseminados de material remobilizado. com destruição das texturas e estruturas gnáissicas originais.

- nível argiloso nodular grosseiro: nível já francamente aloterítico, com cerca de 2,5 m de espessura média, onde a matriz fina amarelada aloterítica caulinfitica-gibbsítica com quartzo e goethita contém grande quantidade de elementos nodulares centimétricos a dominantemente

${ }^{1}$ Departamento de Geologia Geral, Instituto de Geociências e Núcleo de Pesquisa em Geoquímica e Geofísica da Litosfera, USP.

2Iniciação Científica, Departamento de Geologia Geral, Instituto de Geociências, USP

3UNESP. 
de cimétricos. Persistem pseudomorfoses micáceas em caulinita, e a gibbsita pode formar cristalizações grosseiras cutânicas ou não. Os nódulos têm forma arredondada, superfície irregular, e apresentam um núcleo preenchido por material castanho, argiloso, com alta porosidade, friável, com predominância de caulinita fina, e uma parte periférica maciça e coesa, branca, com faixas e volumes avermelhados irregulares, com gibbsita grosseira dominante.

- nível argiloso nodular fino: este nível tem 1,5 m de espessura média e é constituído por matriz argilosa semelhante à do nfvel anterior, mas mais avermelhada. Os nódulos aqui presentes são bem menores, com dimensões predominantemente na faixa de 1 a $3 \mathrm{~cm}$. Morfológica e mineralogicamente, são semelhantes aos do nível anterior.

- solo superficial: aproximadamente $2 \mathrm{~m}$ de espessura tem a cobertura pedológica, que é argilosa, porosa, de cor castanho-amarelada, com caulinita e oxihidróxidos de ferro como constituintes principais do plasma; gibbsita ocorre em pequena quantidade, e quartzo e magnetita bastante alterados constituem o esqueleto. $O$ solo desenvolve-se por evolução do plasma caulinfticogibbsftico dos niveis alterticos, $\theta$ inclui cavidades milimétricas arredondadas revestidas por películas argilosas, morfologicamente semelhantes aos nódulos dos níveis inferiores.

Este perfil bauxítico é essencialmente concordante com estudos anteriores sobre outras ocorrências bauxíticas no SE brasileiro, no que diz respeito às evoluções mineralógicas e morfológicas. A bauxitização quase direta da rocha e a ausência de boehmita denotam as condições de disponibilidade constante de água e de boa drenagem ao longo de sua evolução.

A ocorrência de feições aloteríticas já na base do perfil, inseridas no nivel isalterftico, indica a intensidade dos mecanismos de laterização, embora o perfil seja relativamente pouco espesso, o que deve estar ligado a um período de erosão, após o qual houve formação do horizonte pedológico atual.

A ocorrência de gibbsitização de acordeons de caulinita neoformada soma-se à pequena espessura do perfil para indicar uma possível modificação nas condições de lixiviação do perfil (de origem climática ou topográfica) que, em dada fase, tornou-se mais intensa.

A feição peculiar deste perfil é a presença de feições nodulares correlacionáveis aos elementos endurecidos gibbsitico-ferruginosos raciformes ou vermiformes encontrados em inúmeras outras ocorrências dentro e fora do Brasil, mas completamente divergentes quanto à forma, que, no perfil estudado, assemelha-se às cavidades esféricas organogênicas encontradas no solo, parecendo delas evoluir por migração e acumulação de alumínio no interior do perfil. 